complexity that GPs deal with, including insulin, cytotoxic drugs, gold injections and steroids: other consultants do not share Dr Armond's anxieties.

Lithium has an important role in the management of affective disorders (Cowen, 1988; Gelder et al, 1989), particularly in prevention of recurrence of mania and depression. There is no doubt that the use of lithium does need to be monitored but this is quite easy in general practice, and each doctor should have a plan for monitoring drug levels. My practice is to do levels three-monthly, with an annual check on thyroid and renal function, but some authors (Kehoe \& Marder, 1992) feel that this policy is too strict. We need to develop and improve good practice (Aronson \& Reynolds, 1992) so that as many people as possible can be treated in the community rather than attending hospitals or local mental health units for blood testing. This issue is not being driven by fund-holding but by good clinical practice.

ARONSON. J. K. \& REYNOLDS, D. J. M. (1992) Lithium. British Medical Journal, s06, 1273-1276.

BROWN, P. (1993) Ethical aspects in drug treatment. In Psychiatric Ethics (2nd ed.) (eds S. Bloch and P. Chodoff) Oxford:Oxford Untversity Press.

CowEN, P. J. (1988) Depression resistant to tricyclic antidepressants. British Medical Journal, 297, 435.

GelDER, M., GATH, D. \& MAYOU, R. (1989) Drugs and other physical treatments. In Oxford Textbook of Psychiatry (2nd Ed). Oxford:Oxford University Press.

KEHOE, R. F. \& MANDER, A. J. (1992) Lithium treatment: prescribing and monitoring habits in hospital and general practice. British Medical Journal, 304, 552-554.

Dominic H. R. FAux, 'Albion House', Albion Street, Brierley Hill, West Midlands DY5 $3 E E$

Sir: I am glad to reply to Dr D. Faux's letter about general practitioners (GPs) prescribing lithium. The British National Formulary, some computer programmes in general practice and several psychiatrists, including myself, (Prescriber, 1991, 38, 81-83) have apparently not been very successful in contributing to the safety of lithium prophylaxis in general practice.

Of 1250 consecutive lithium estimations over several months in 1994 in our borough of 305000 population, 5 out of the 6 levels above $1.2 \mathrm{mmol} / 1$ were found in patients in GPs' care only, even though the vast majority of patients on lithium were in consultant care.
In my original letter, 'General Practitioners and Lithium', Psychiatric Bulletin, 19, 117) research in Edinburgh was quoted as showing that where GPs controlled lithium prophylaxis with advice and reminders from the central hospital, the admission rate for mania rose enormously instead of falling by over $70 \%$ as in my clinic and the drop-out rate was 10 times that found in my clinic.

Now, Dr S. Noblett's audit in Macclesfield reveals that "the level of monitoring of serum lithium, renal and thyroid function, is far superior in those patients who attend the clinic nurse in the out-patient department compared to those monitored by the community psychiatric nurse or general practitioner in the community"; and default or non-compliance bring about an immediate follow up.

There is no doubt that a GP can monitor lithium maintenance satisfactorily if prepared to become well informed and to remain up to date, and if it is fully realised that such lithium monitoring is only one part of a much bigger project to keep a manic-depressive patient as well as possible-without which, lithium does more harm than good.

A. D. ARMOND (Former general practitioner), Consultant Psychiatrist, Bushey Fields Hospital, Bushey Fields Road, Dudley, West Midlands DY1 2LZ

\section{Consent, decision making and Common Law}

Sir: We were interested to read The emergency treatment of overdose: a problem of consent to treatment' by Hardie et al (Psychiatric Bulletin. January 1995, 19, 7-9). We welcomed the highlighting of this legally and ethically important topic. However, we have concerns about the methodology and the finding that "there was no clear consensus as to the correct choice of action".

The method involved forced choice responses regarding the management of a vignette. It is doubtful whether answers about a single vignette, particularly given the limited range of choices, adequately reflect clinical practice. Importantly the issue of allowing patients to leave without treatment was not addressed, this being a critical issue in reality. Of the responses available, $75 \%$ entailed forced treatment of the patient at some time. Thus, there was a bias towards treatment in the 